\title{
The formation of passive margins: constraints from the crustal structure and segmentation of the deep Galicia margin, Spain
}

\author{
G. BOILLOT, ${ }^{1}$ M. O. BESLIER, ${ }^{1}$ C. M. KRAWCZYK, ${ }^{2}$ D. RAPPIN ${ }^{3}$ \\ \& T. J. RESTON ${ }^{2}$ \\ ${ }^{1}$ Observatoire Océanologique de Villefranche, Laboratoire de Géodynamique Sous-Marine, \\ B.P. 48, 06230 Villefranche-Sur-Mer, France \\ ${ }^{2}$ GEOMAR, Forschungszentrum für Marine Geowissenchaften, Christian-Albrechts \\ Universität, Wischhofstrasse 1-3, 2300 Kiel, Germany \\ ${ }^{3}$ Ecole et Observatoire de Physique du Globe de Strasbourg, URA CNRS 323, ULP, 5 rue \\ Descartes, 67084 Strasbourg Cedex; now at Elf Aquitaine Production, Centre Scientifique et \\ Technique, 64018 PAU Cedex, France
}

\begin{abstract}
The crustal structure of the Mesozoic deep Galicia margin and adjacent oceancontinent boundary $(\mathrm{OCB})$ was investigated by seismic reflection (including pre-stack depth migration and attenuation of seismic waves with time). The seismic data were calibrated using numerous geological samples recovered by drilling and/or by diving with submersible.

The N-S trending margin and OCB are divided in two distinct segments by NE-SW synrift transverse faults locally reactivated and inverted by Cenozoic tectonics. The transverse faulting and OCB segmentation result from crustal stretching probably in a NE-SW direction during the rifting stage of the margin in early Cretaceous times. The Cenozoic tectonics are related to Iberia-Eurasia convergence in Palaeogene times (Pyrenean event). In both segments of the deep margin, the seismic crust is made of four horizontal layers: (1) two sedimentary layers corresponding to post- and syn-rift sequences, where velocity ranges from 1.9 to $3.5 \mathrm{~km} \mathrm{~s}^{-1}$, and where the $Q$ factor is low, the two sedimentary layers being separated by a strong reflector marking the break-up unconformity; (2) a faulted layer, where velocity ranges from 4.0 to $5.2 \mathrm{~km} \mathrm{~s}^{-1}$, and where the $Q$ factor is high. This layer corresponds to the margin tilted blocks, where continental basement and lithified pre-rift sediments were sampled; (3) the lower seismic crust, where the velocity $\left(7 \mathrm{~km} \mathrm{~s}^{-1}\right.$ and more) and the $Q$ factor are the highest. This layer, probably made of partly serpentinized peridotite, is roofed by a strong $\mathrm{S}-\mathrm{S}^{\prime}$ seismic reflector, and resting on a scattering, poorly reflective Moho.

A composite model, based both on analogue modelling of lithosphere stretching and on available structural data, accounts for the present structure of the margin and OCB. Stretching and thinning of the lithosphere are accommodated by boudinage of the brittle levels (upper crust and uppermost mantle) and by simple shear in the ductile levels (lower crust and upper lithospheric mantle). Two main conjugate shear zones may account for the observations and seismic data: one (SZ1), located in the lower ductile continental crust, is synthetic to the tilting sense of the margin crustal blocks; another (SZ2), located in the ductile mantle, accounts for the deformation of mantle terranes and their final unroofing and exposure at the continental rift axis (now the OCB). The $\mathrm{S}-\mathrm{S}^{\prime}$ reflector is interpreted as the seismic signature of the tectonic contact between crustal terranes and mantle rocks partly transformed into serpentinite by syn-rift hydrothermal activity. It is probably related to both shear zones SZ1 and SZ2. The seismic Moho is lower within the lithosphere, at the fresh-serpentinized peridotite boundary.
\end{abstract}

Passive continental margins are the scars of the break-up of continents. Their basement underwent stretching before seafloor spreading started, and contains crucial information about timing and pressure-temperature conditions of lithospheric deformation due to extensional tectonics. Unfortunately, as passive margins are also places where subsidence was important and rapid, in general the crust is covered by a thick sedimentary layer which prevents observation and sampling of the basement.

The West Galicia margin (Fig. 1) is exceptional in that it is a starved margin, covered only by a thin and discontinuous sedimentary layer. These conditions are favourable for imaging by seismic reflection the thinned continental crust and the crustal ocean-continent boundary (OCB), and also to sample the basement by 


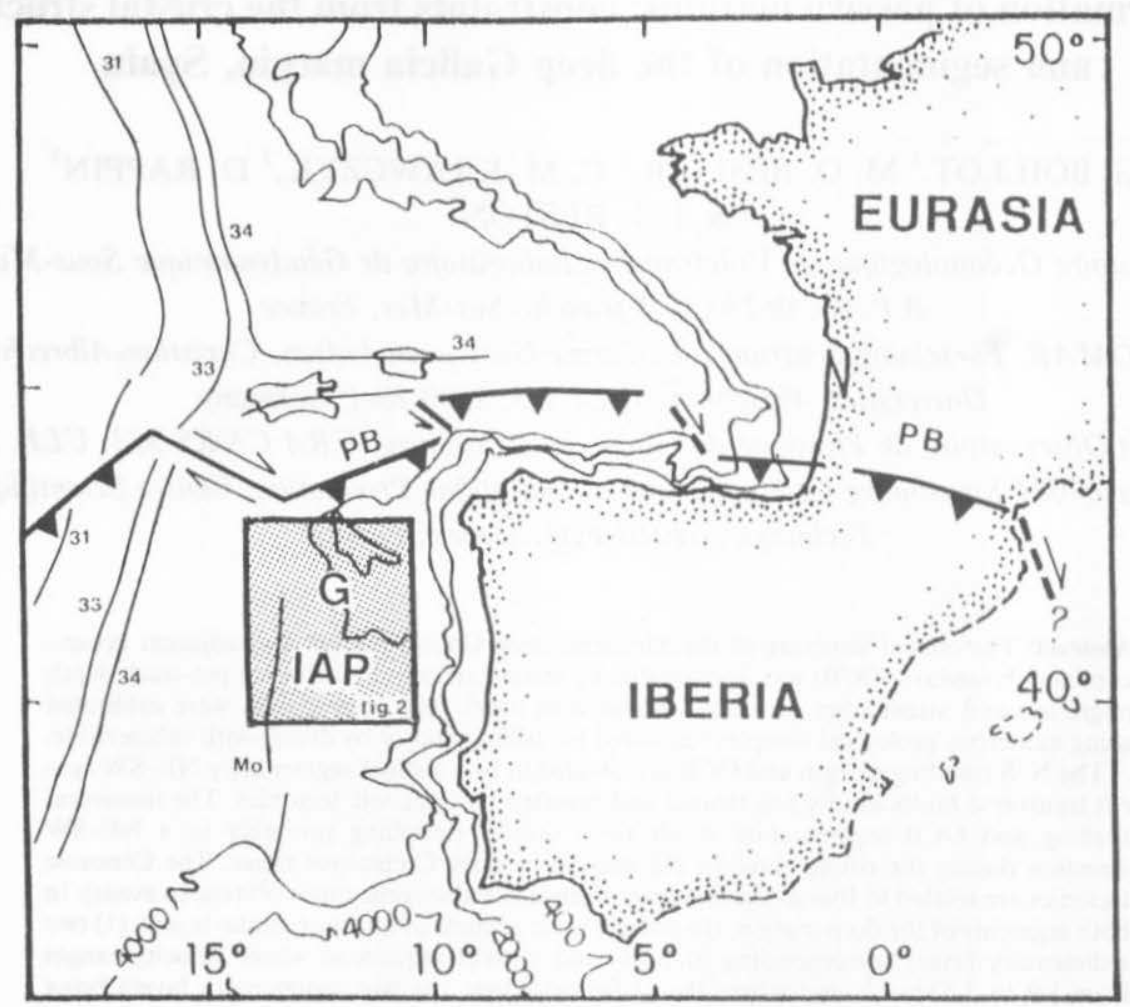

Fig. 1. Location of the studied area. Magnetic anomalies Mo and 31-34 from Srivastava et al. (1990). PB, Palaeocene plate boundary after Grimaud et al. (1982). G, Galicia margin; IAP, Iberia Abyssal Plain.

drilling or even by diving with the French submersible 'Nautile'. For that reason, the Galicia margin has been intensively studied for 20 years (see recent synthesis in Mauffret \& Montadert 1987; Sibuet et al. 1987; Boillot et al. $1988 b, 1989 a)$.

However, as the OCB and the main extensive structures of the margin are trending $\mathrm{N}-\mathrm{S}$, the seismic data were generally recovered along $\mathrm{E}-$ $\mathrm{W}$ lines. For that reason, transverse structures were poorly imaged, although recognized in some places (Thommeret et al. 1988). To fill this gap, in 1990 we recorded (Lusigal cruise) several $\mathrm{N}-\mathrm{S}$ seismic lines on the eastern, continental side of the OCB (Fig. 2, inset), so discovering that the West Galicia margin is actually made of two distinct segments separated by a major transverse structure. Moreover, a recent study of the Iberia Abyssal Plain (Beslier et al. 1993) revealed a segmented structure for the deep margin and OCB in the area located to the south of the Galicia margin (Fig. 2). In this paper we focus on the segmentation and the crustal structure of the deep Galicia margin and adjacent OCB.

\section{Segmentation of the ocean-continent boundary (OCB) offshore Galicia}

The West Galicia margin results from lithosphere stretching and rifting during lower Cretaceous times, lasting from 140 to $114 \mathrm{Ma}$ (Boillot et al. 1987b, 1988c; time scale after Kent \& Gradstein 1986). Accordingly, the M0 $(118 \mathrm{Ma})$ magnetic anomaly is recognized offshore Portugal, while it is missing offshore Galicia (Fig. 1) where the margin is bounded by the Cretaceous quiet magnetic zone (Srivastava et al. 1990).

\section{The segmented ocean-continent boundary}

The OCB to the west of Galicia is marked by a basement ridge made of serpentinized peridotite. The ultramafic basement was sampled in several locations by dredging (Boillot et al. 1980; Sibuet et al. 1987), by drilling (leg ODP 103, drill Site 637; Boillot et al. 1987b, 1988c) or by diving with the Nautile (Boillot et al. 1988a). It separates two areas with different seismic and structural 


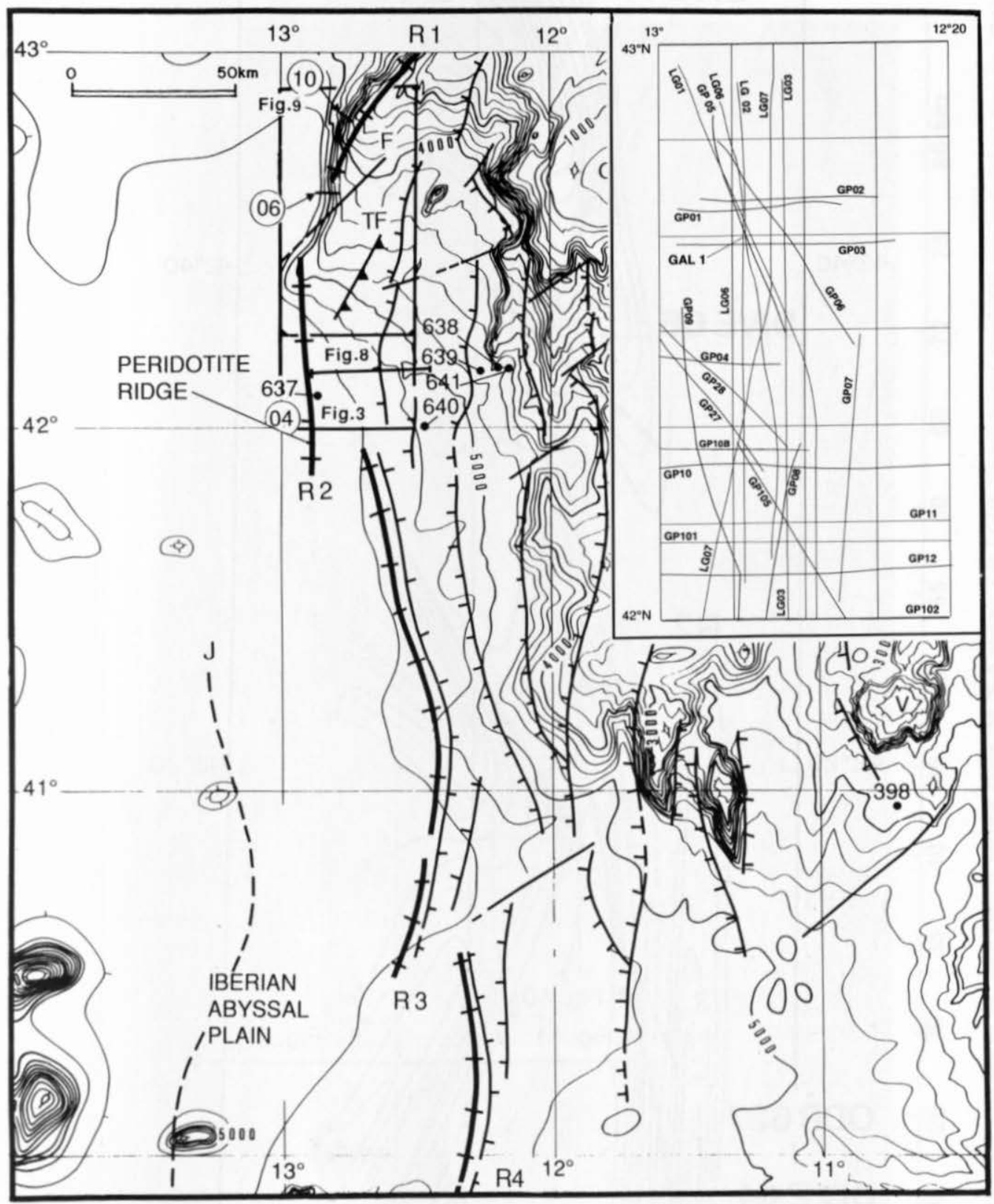

Fig. 2. Structural map of the West Iberia passive margin north of $40^{\circ} \mathrm{N}$, after Beslier et al. (1993) (location on Fig. 1). J anomaly from Whitmarsh et al. (1990). Structural map of the Galicia margin after Thommeret et al. (1988) and Murillas et al. (1990). R1-R4, segments of the ridge bounding the oceanic and continental domains. Bathymetry after Lallemand et al. (1985). V, Vigo seamounts. DSDP Leg 47b and ODP Leg 103 sites, and dive sites (circled numbers) where peridotite was sampled are indicated. Inset: track map of multichannel seismic lines used in the study of the deep Galicia margin. 


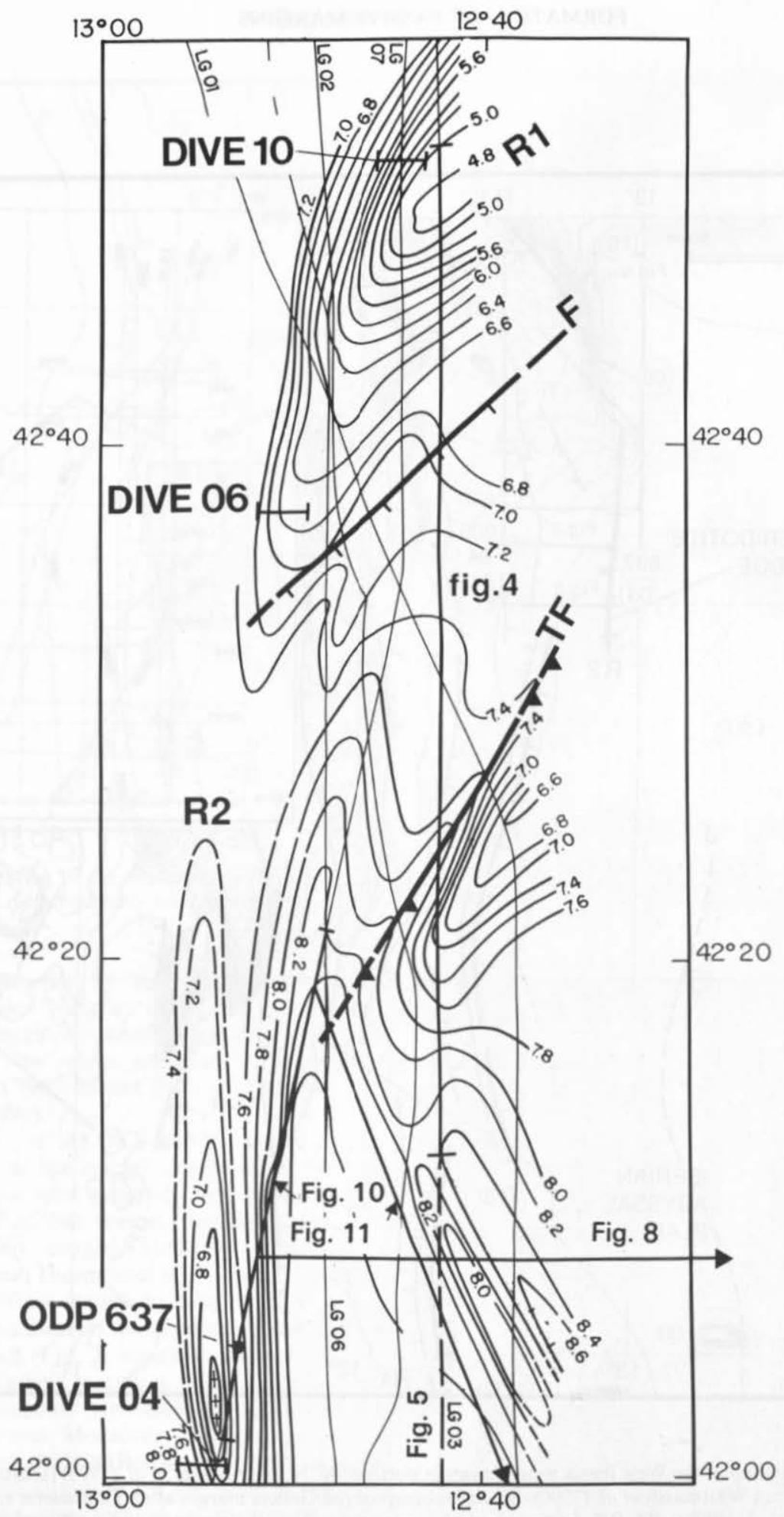

Fig. 3. Depth to the break-up unconformity (BU) (in $s$ twt). Ultramafic basement, faulted enigmatic terrane or syn-rift sediment are resting beneath BU, in different places. Drill and dive sites where samples of serpentinized peridotite were recovered are indicated. F and TF, Mesozoic and Cenozoic transverse faults, respectively. 


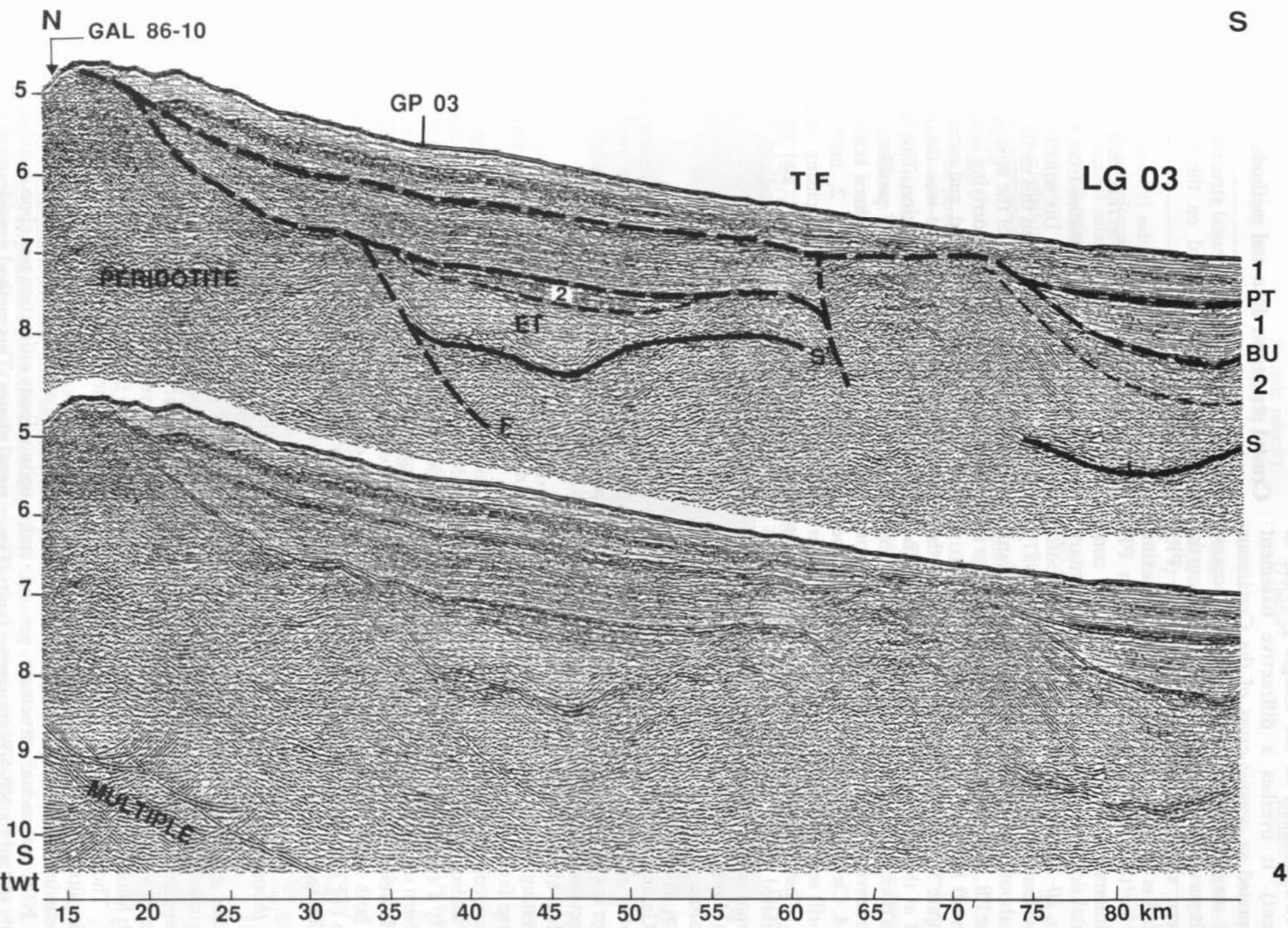

Fig. 4. Image of the crustal structure of the deep Galicia margin along the N-S seismic line LG03. Serpentinized peridotite was sampled at dive site GAL 86.10. ET, enigmatic terrane, including faulted continental basement and lithified sediments. ET is overlain by syn- (2) and post-rift (1) sediments separated by the break-up unconformity BU. F and TF, Mesozoic and Cenozoic transverse faults, respectively. S and S', S and S' seismic reflectors, considered in the paper as the seismic signature of the tectonic contact between serpentinized peridotite and crustal terranes, broken by the Cenozoic transverse fault TF. PT, seismic reflector located at the bottom of sediment deposited after the tectonic activity of TF in late Palaeogene time. A better image of TF is shown on Fig. 5. Location on Figs 3, 5 \& 9. 
characters. On the oceanic side, to the west, the relatively thin sedimentary layer is related to post-rift sediments of the margin (114 Ma to Present). It overlies a diffractive basement interpreted as oceanic crust of the Cretaceous quiet magnetic zone. In fact, Albian oceanic basalt was observed and sampled on the northwestern slope of the peridotite ridge (PR) (Malod et al. 1993), and infered from refraction data to the west of the Galicia margin PR (Whitmarsh et al. 1993). On the eastern continental side the PR is bounded by a sedimentary basin, $10-20 \mathrm{~km}$ wide, infilled by syn- and postrift sediments (Mauffret \& Montadert 1987). Hereabouts, syn-rift sediments overlap the flank of the PR, indicating that this part of the ridge is a syn-rift feature.

Figure 3 shows the present morphology of the $\mathrm{OCB}$ at the bottom of post-rift sediments. The $P R$ is divided into two segments, $R 1$ and $R 2$, by the transverse faults $\mathrm{F}$ and TF, both imaged on Fig. 4. Clearly, TF disturbs the lower part of the post-rift sequence, while it is sealed by the upper part. The oldest deformed sediments can be correlated with Paleogene strata, according to regional seismic stratigraphy calibrated by drilling (Mauffret \& Montadert 1987). Thus, TF is a Cenozoic structure, related to Pyrenean tectonics, as are many other faults in that part of the Galicia margin (Boillot et al. 1979; Mougenot et al. 1984; Malod et al. 1993). Its seismic image is confused on Fig. 4 owing to a lot of diffraction events. It is clearer on the record of residual attenuation of seismic waves (Fig. 5A), suggesting a transpressional strike-slip fault or a reverse fault, as expected for structures related to Cenozoic plate convergence. On the contrary, $\mathrm{F}$ is sealed by the break-up unconformity. It is clearly a syn-rift normal fault which bounds the northern segment R1 of the peridotite ridge (Fig. 4). However, its setting parallel to TF suggests that both faults are Mesozoic structures, one of them (TF) having been reactivated and inverted by Cenozoic tectonics.

\section{The thinned continental crust of the margin}

Further east, the upper crust of the Galicia margin consists of tilted blocks, $16 \mathrm{~km}$ across on average and bounded westward by N-S normal faults or sets of normal faults (Montadert et al. 1979; Mauffret \& Montadert, 1987; Sibuet et al. 1987; Thommeret et al. 1988). The eastward block tilting involved the formation of halfgrabens infilled by syn- and post-rift sediments. The N-S extensional structures are cut and locally shifted by NE-SW transverse faults (Fig. 2; Thommeret et al. 1988), which are possibly transfer faults related to the margin segmentation.

\section{Crustal structure: data and methods}

Our interpretation of the crustal structure of the segmented margin is based on the following analyses.

\section{Seismic velocities from reflection data}

First we derived interval velocities from normal moveout velocities, using the Dix equation (Dix 1955). Because of its limitations this method was applied only to the portions of the seismic lines where the seafloor and the underlying layers are close to horizontal. The second, and more timeconsuming, approach adopted was the use of iterative pre-stack depth migration. This has, to date, been applied to two E-W profiles: GP102 and GP03, one from the southern region and one from the northern (Fig. 2, inset). The method is based on depth-focusing analysis (see Reston et al. this volume), and provides more meaningful estimates of velocity in the structures.

\section{Seismic refraction}

The data recently published by Whitmarsh et al. (in press), related to two seismic refraction profiles fired across the OCB of Galicia along $42^{\circ} 10^{\prime} \mathrm{N}$, was used.

\section{Amplitude attenuation of recorded waves}

This method consists of measuring the amplitude variations of seismic signals with time (see details in Rappin et al. in press). The results of a simple modelling of attenuation can be represented in two different images: (1) the distribution of the quality factor $Q$ with time and shot location (Fig. 5A). The $Q$ factor is one of the parameters used to perform the modelling of attenuation $v$. time. It is related to both absorption and scattering by interfaces and terrane heterogeneities. Its value decreases in particular where heterogeneities have a size close to the wavelength $(c .100 \mathrm{~m})$, for example in deformed zones; (2) the residual attenuation of seismic waves with time and shot location (Fig. 5B). This is the difference between the calculated and the measured curves of seismic waves attenuation. As it estimates the most coherent amplitude of the seismic wave it does not depend upon velocity estimation nor upon correlation of signal phases. This method provides an apparent reflectivity of terranes, and gives a more 
Table 1. Values of the $\mathrm{Q}$ factor, reflectivity and seismic velocities within layers $1-4$ in the northern and southern segments of the deep Galicia margin

\begin{tabular}{|c|c|c|c|c|c|c|}
\hline & \multicolumn{2}{|c|}{$\begin{array}{l}\text { Seismic velocity } \\
\left(\mathrm{km} \mathrm{s}^{-1} \text {, twt }\right)\end{array}$} & \multicolumn{2}{|c|}{$Q$ factor* } & \multicolumn{2}{|c|}{ Reflectivity* } \\
\hline & $\begin{array}{l}\text { Northern } \\
\text { segment* }\end{array}$ & $\begin{array}{l}\text { Southern } \\
\text { segment } \dagger\end{array}$ & $\begin{array}{l}\text { Northern } \\
\text { segment }\end{array}$ & $\begin{array}{l}\text { Southern } \\
\text { segment }\end{array}$ & $\begin{array}{l}\text { Northern } \\
\text { segment }\end{array}$ & $\begin{array}{l}\text { Southern } \\
\text { segment }\end{array}$ \\
\hline Layer 1: post-rift sediments & $2.15-2.66$ & $1.9-3.0$ & $10-11$ & $4.0-4.5$ & - & - \\
\hline Break-up unconformity & - & - & - & - & $0.4-0.6$ & $0.25-0.35$ \\
\hline Layer 2: syn-rift sediments & $3.0-4.5$ & 3.5 & - & $90-200$ & - & - \\
\hline $\begin{array}{l}\text { Layer } 3 \text { : pre-rift sediments } \\
\text { and basement }\end{array}$ & $4.0-5.7$ & $4.0-5.1$ & $600-650$ & $600-675$ & - & - \\
\hline $\mathrm{S}-\mathrm{S}^{\prime}$ seismic reflector & - & - & - & - & $0.2-0.25$ & $0.15-0.35$ \\
\hline $\begin{array}{l}\text { Layer } 4 \text { : serpentinized } \\
\text { peridotite }\end{array}$ & - & $7.0-7.8$ & $800-950$ & $850-950$ & - & - \\
\hline Seismic Moho & - & - & - & - & $0.1-0.15$ & $0.15-0.2$ \\
\hline Layer 5: fresh peridotite & - & 8.1 & 1000 & 1000 & - & - \\
\hline
\end{tabular}

* Results of this study. Reflectivity values are calculated with respect to a value of 1 at the seafloor.

$\dagger$ After Hoffmann \& Reston (1992) for the layers overlying S; Horsfield (1992) and Whitmarsh et al. (1993) for layers 4 and 5 , respectively.

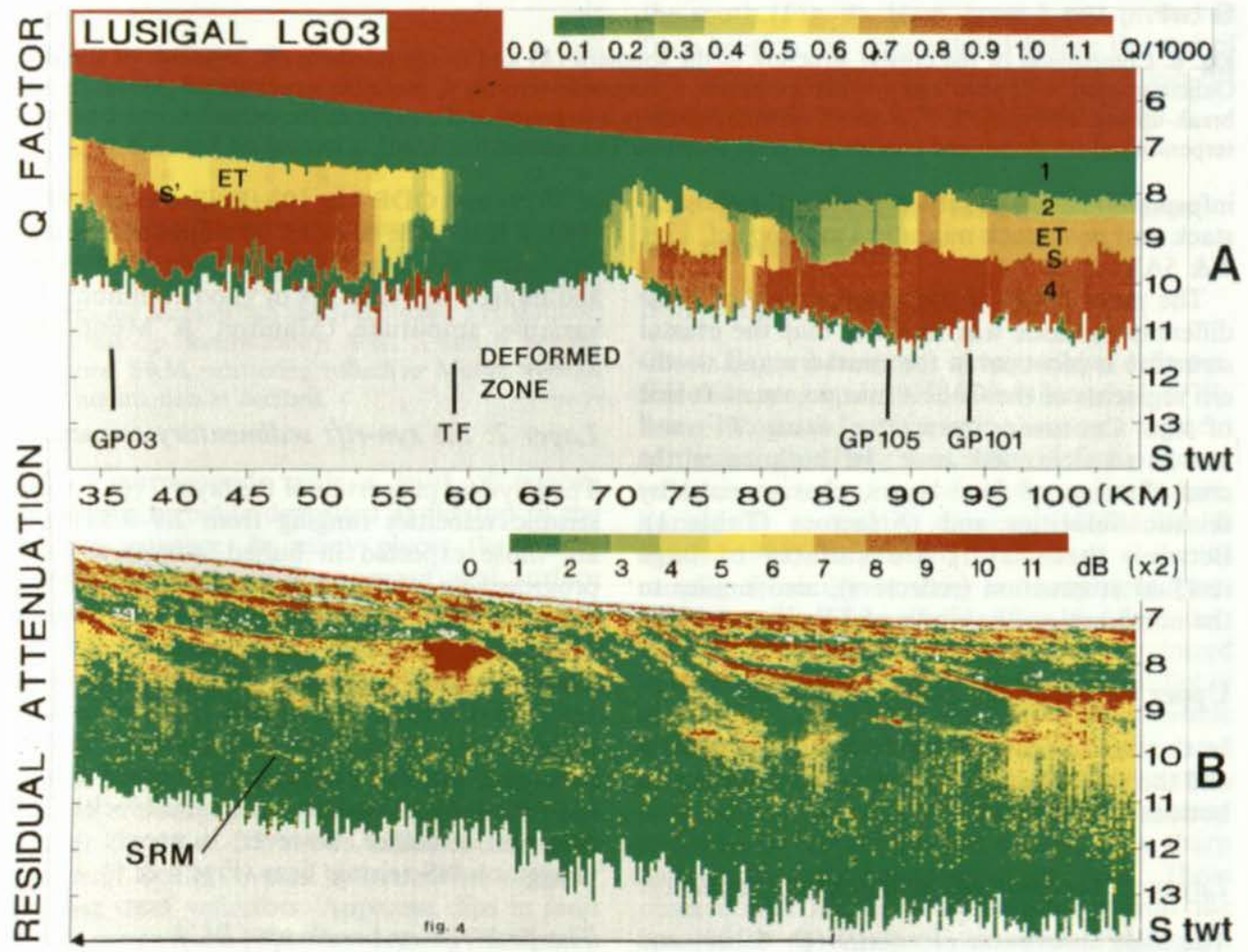

Fig. 5. (A) Values of the attenuation factor $Q$ along a section of the seismic line LG03. 1-2, post- and syn-rift sediments; ET, enigmatic terranes, including continental basement and lithified sediments; 4 , lower seismic crust, probably made of serpentinized peridotite hereabouts; SRM, Scattering reflective Moho. Location on Fig. 3. (B) Values of the residual attenuation of seismic waves along the same seismic line (compare with Figs 4 \& 6 ). Location on Fig. 3. 


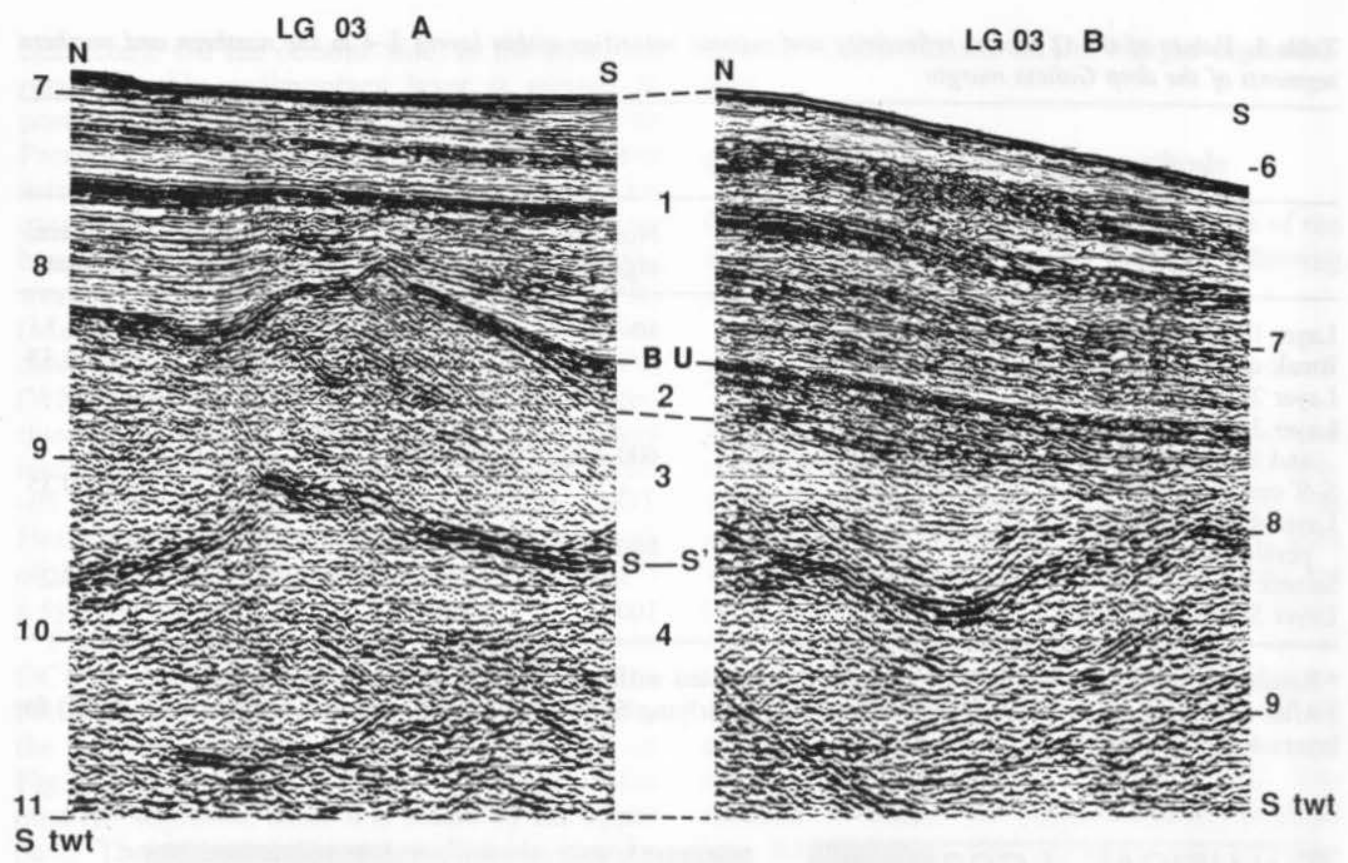

Fig. 6. Comparison of the crustal structure in the southern (A) and in the northern (B) segments of the deep Galicia margin. 1-2, post- and syn-rift sediments; 3, enigmatic terrane; 4, probable serpentinized peridotite; BU, break-up unconformity; $\mathbf{S}, \mathbf{S}^{\prime}, \mathbf{S}$ and $\mathbf{S}^{\prime}$ seismic reflectors interpreted in the paper as the tectonic contact between serpentinized peridotite and continental crust material. The seismic line LG03 is located on Figs 3 \& 9.

informative image of reflectors than the classical stack and post-stack migration method (cf. Figs 4 \& 5A).

The main result of the combination of these different methods was to show that the crustal structure is identical in the southern and northern segments of the Galicia margin, on each side of the Cenozoic transverse fault TF and associated deformed zone. In both cases the crust consists of four layers, characterized by seismic velocities and $Q$ factors (Table 1). Between these layers are surfaces of large residual attenuation (reflectors), also similar to the north and to the south of TF (Figs $6 \&$ \%).

\section{Upper layers of the continental crust}

In this section crustal layers 1-3 are described and their probable geological nature from top to bottom considered.

\section{Layer 1: the post-rift sedimentary sequence.}

The high absorption of energy $(Q<100)$ and the low seismic velocities $\left(1.9-2.6 \mathrm{~km} \mathrm{~s}^{-1}\right)$ measured within layer 1 are in good agreement with the physical properties of non- or poorlyconsolidated sediments. Layer 1 was drilled in several places during DSDP Leg 47b (Sibuet et al. 1979) and ODP Leg 103 (Boillot et al. 1987b, $1988 c$ ). It is made of distal turbidites and pelagic sediments, deposited from $114 \mathrm{Ma}$ to Present, and imaged by reflectors of good continuity but variable amplitude (Mauffret \& Montadert, 1988).

\section{Layer 2: the syn-rift sedimentary sequence}

The physical properties of the layer $2(Q=100$; seismic velocities ranging from $2.9-3.5 \mathrm{~km} \mathrm{~s}^{-1}$ ) are those expected in buried, compacted and progressively lithified sediments. At the drill Site 639 (Leg ODP 103), layer 2 is made of coarse, siliciclastic turbidite and sandstone and by alternating clay and marl, lower Cretaceous in age (135-114 Ma). The seismic facies of layer 2 ranges from chaotic to well layered, with a divergent, fan-like configuration related to the syn-rift tilting of underlying crustal blocks. The divergent structure, however, is poorly or not imaged on NS seismic lines (Figs 4 \& 6).

\section{The post-rift or break-up (BU) unconformity}

This is marked by a strong reflector and a high positive residual attenuation level located between layers 1 and 2. At drill Site 641 (Leg ODP 

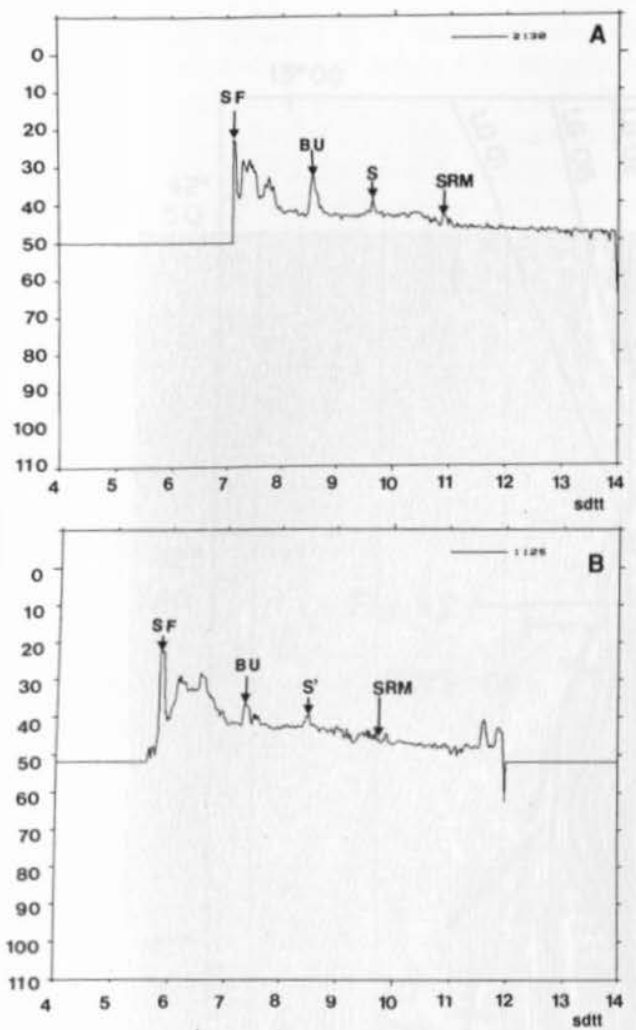

Fig. 7. Attenuation curves of seismic waves through the southern (A) and northern (B) segments of the Galicia margin. Attenuation rates and reflection patterns are identical on the two curves. SF, seafloor; $\mathrm{BU}$, break-up unconformity; $\mathrm{S}-\mathrm{S}^{\prime}, \mathrm{S}$ and $\mathrm{S}^{\prime}$ seismic reflectors; SRM, scattering reflective Moho; vertical scale, attenuation in decibels.

103) it corresponds with a level of coarse, calcareous turbidite deposited at the top of the syn-rift sequence. In many places the BU is also an erosional or non-depositional surface (Mauffret \& Montadert 1987).

\section{Layer 3: faulted terrane or enigmatic terrane (ET)}

Within layer $3 Q$ ranges from 600 to 675 , and the seismic velocity from 4.0 to $5.7 \mathrm{~km} \mathrm{~s}^{-1}$. The seismic image of ET shows diffractive acoustic basement locally covered by horizontal to gently dipping weak reflectors. Apparent dips in fault blocks range from $40^{\circ}$ to few degrees (Hoffmann \& Reston 1992). On the N-S seismic line LG 03 (Fig. 4) dipping reflections in layer 3 are also apparent just to the south of TF, and may represent pre-rift sediments tilted by movement along TF.
Layer 3 was sampled in the southern part of the margin, at dive Site 11 (Fig. 8). Here, the westernmost, deepest tilted crustal block is cropping out on the seafloor, allowing the Nautile to recover on a normal fault scarp several samples of granodiorite from the Hercynian upper crust. The continental basement is covered by Mesozoic pre-rift limestones and sandstones (Boillot et al. 1988a). However, ET may also include other terranes with similar physical properties, for example volcanic rocks, although the margin is devoid of significant magnetic anomaly, or Palaeozoic, poorly metamorphozed sediments as those recovered at another site on the margin by Mamet et al. (1991). In our opinion, a correct characterization of the enigmatic terrane remains an important target. It is crucial to verify its geological nature to constrain the interpretation of the underlying $\mathrm{S}$ reflector (see the next section).

Enigmatic terranes are thickened within a synrift graben bounded by $\mathrm{F}$ to the north and TF to the south (Fig. 9). Here, layer 3 was preserved from erosion, or accumulated before the end of the rifting, confirming that TF was a syn-rift structure before its Cenozoic reactivation.

\section{S-S' seismic reflector, lower seismic crust and reflective Moho}

\section{$S-S^{\prime}$ seismic reflectors}

Crustal layer 3 rests on a strong seismic reflector, S (de Charpal et al. 1978; Montadert et al. 1979). $S$ was recognized at first in the southern segment of the margin. Here it is either a single, strong reflector, or a sequence of elementary reflectors, horizontal to gently dipping (Hoffmann \& Reston 1992). In general, S is located at depths ranging from 0.6 to $1.5 \mathrm{~s}$ two-way time (twt) from the top of layer 3 (Mauffret \& Montadert 1987). $S^{\prime}$ is a similar reflector recently recognized in the northern segment of the margin (Boillot $e t$ al. 1992). It is characterized by the same seismic signature as $\mathrm{S}$ (Fig. 7), and occurs at the same structural level (Fig. 6). More precisely, amplitude analyses show that $\mathbf{S}$ and $\mathbf{S}^{\prime}$ have the same signature in the attenuation curves, i.e. a sharp and significantly high amplitude peak. These observations are in good agreement with the occurrence at depth of an abrupt geological interface between terranes very different in nature, rather than with a progressive geological transition, the expected signature of which being a reflection zone (and not a strong reflector), and a wide (and not a sharp) peak of small amplitude 

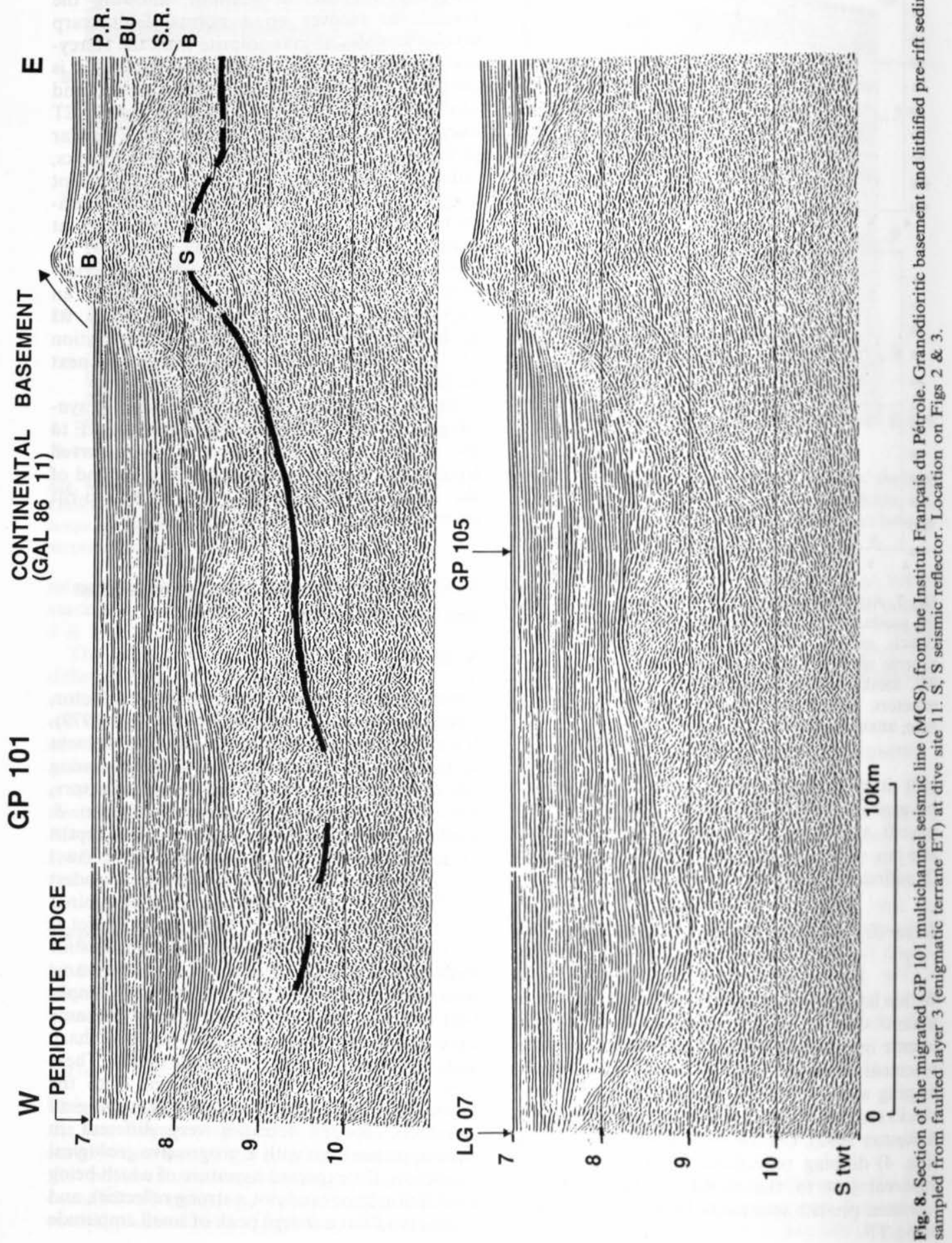


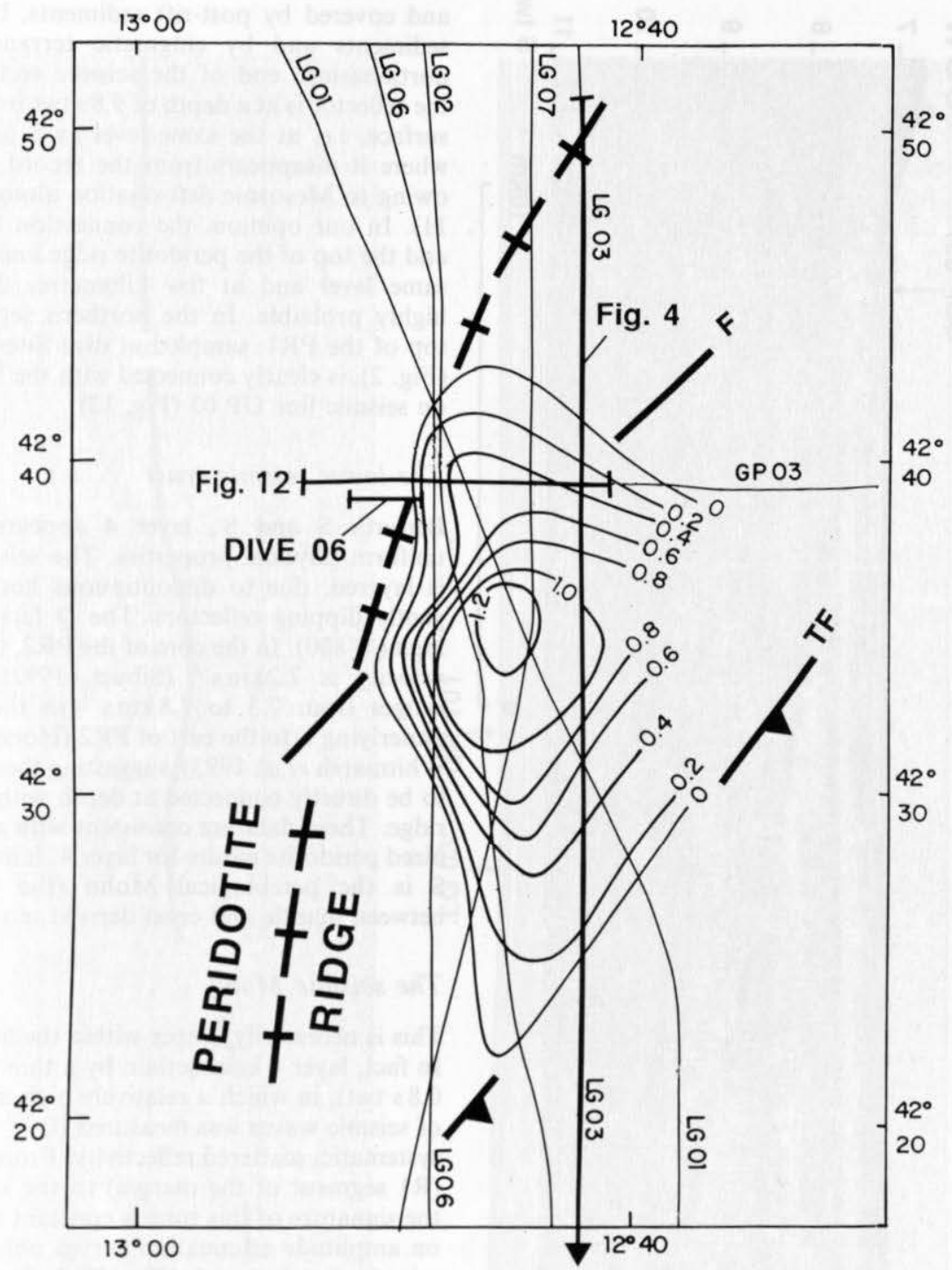

Fig. 9. Thickness of the layer 3 (enigmatic terrane ET) (in s twt). The velocity within layer 3 ranges from 4 to $5.7 \mathrm{~km} \mathrm{~s}^{-1}$. F and TF, Mesozoic and Cenozoic transverse faults, respectively. Location on Fig. 2.

in the attenuation curves. Moreover, the attenuation variations and parameters within terranes over- and underlying $\mathrm{S}$ are remarkably similar to those over- and underlying S' (Figs 5 \& 6).

The significance of $\mathbf{S}^{-S^{\prime}}$ and the geological nature of related terranes remains controversial (see the discussion in the next section and in Reston et al. this volume). However, recent multichannel seismic data allowed the tentative connection of both $\mathrm{S}$ and $\mathrm{S}^{\prime}$ to the top of the serpentinite terranes sampled on the two segments of the peridotite ridge bounding the margin (Boillot et al. 1992). For the southern segment, Fig. 10 shows a section of seismic line LG 07 from the top of the PR2, where ultramafic rocks were drilled, to the axis of the sedimentary basin bounding the ridge to the east. The roof of the serpentinite body forms a strong reflector dipping northeast. From south- 


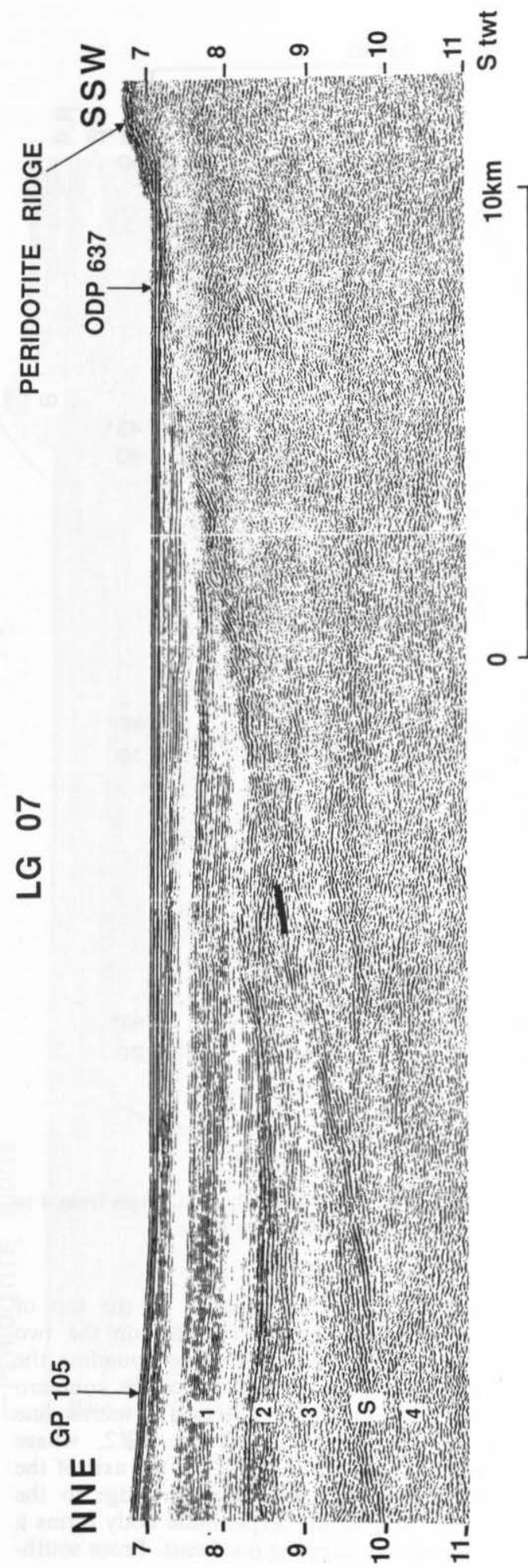

west to northeast it is progressively deepening and covered by post-rift sediments, by syn-rift sediments and by enigmatic terranes at the north-eastern end of the seismic section. Here the reflector is at a depth of $9.8 \mathrm{~s} \mathrm{twt}$ from the sea surface, i.e. at the same level as S on GP 105 where it disappears from the record, probably owing to Mesozoic deformation along TF (Fig. 11). In our opinion, the connection between $S$ and the top of the peridotite ridge imaged at the same level and at few kilometres distance is highly probable. In the northern segment, the top of the PR1, sampled at dive Sites 6 and 10 (Fig. 2), is clearly connected with the $\mathrm{S}^{\prime}$ reflector on seismic line GP 03 (Fig. 12).

\section{The lower seismic crust}

Beneath $\mathrm{S}$ and $\mathrm{S}^{\prime}$, layer 4 appears to have uniform physical properties. The seismic facies is layered, due to discontinuous horizontal or gently dipping reflectors. The $Q$ factor is very high $(>800)$. In the core of the PR2, the seismic velocity is $7.2 \mathrm{~km} \mathrm{~s}^{-1}$ (Sibuet, 1992), while it ranges from 7.3 to $7.8 \mathrm{~km} \mathrm{~s}^{-1}$ in the terranes underlying $\mathrm{S}$ to the east of PR2 (Horsfield 1992; Whitmarsh et al. 1993), suggesting these terranes to be directly connected at depth with the OCB ridge. These data are consistent with a serpentinized peridotite nature for layer 4 . It implies that $\mathrm{S}$ is the petrological Moho (the boundary between mantle and crust derived terranes).

\section{The seismic Moho}

This is necessarily deeper within the lithosphere. In fact, layer 4 is underlain by a thin zone ( 0.2 $0.8 \mathrm{~s}$ twt), in which a relatively high attenuation of seismic waves was measured $(Q<100)$, with systematic, scattered reflectivity. From the north (R1 segment of the margin) to the south (R2), the signature of this zone is constant and typical on amplitude attenuation curves obtained from seismic signal records (Figs 5B \& 7).

The weakness and the scattering character of the reflectivity at the bottom of layer 4 is different from other overlying seismic reflectors. The strong attenuation implies the presence of heterogeneities whose size is close to the wavelength of the signal $(100-200 \mathrm{~m})$, which induces a maximum of scattering (Herraiz \&

Fig. 10. Section of the migrated LG07 MCS line, where the top of the peridotite ridge is imaged and can be connected at depth with the S seismic reflector. 1, 2,3, 4 , post-rift sediments, syn-rift sediments, enigmatic terranes and serpentinized peridotite, respectively. Location on Fig. 3. 

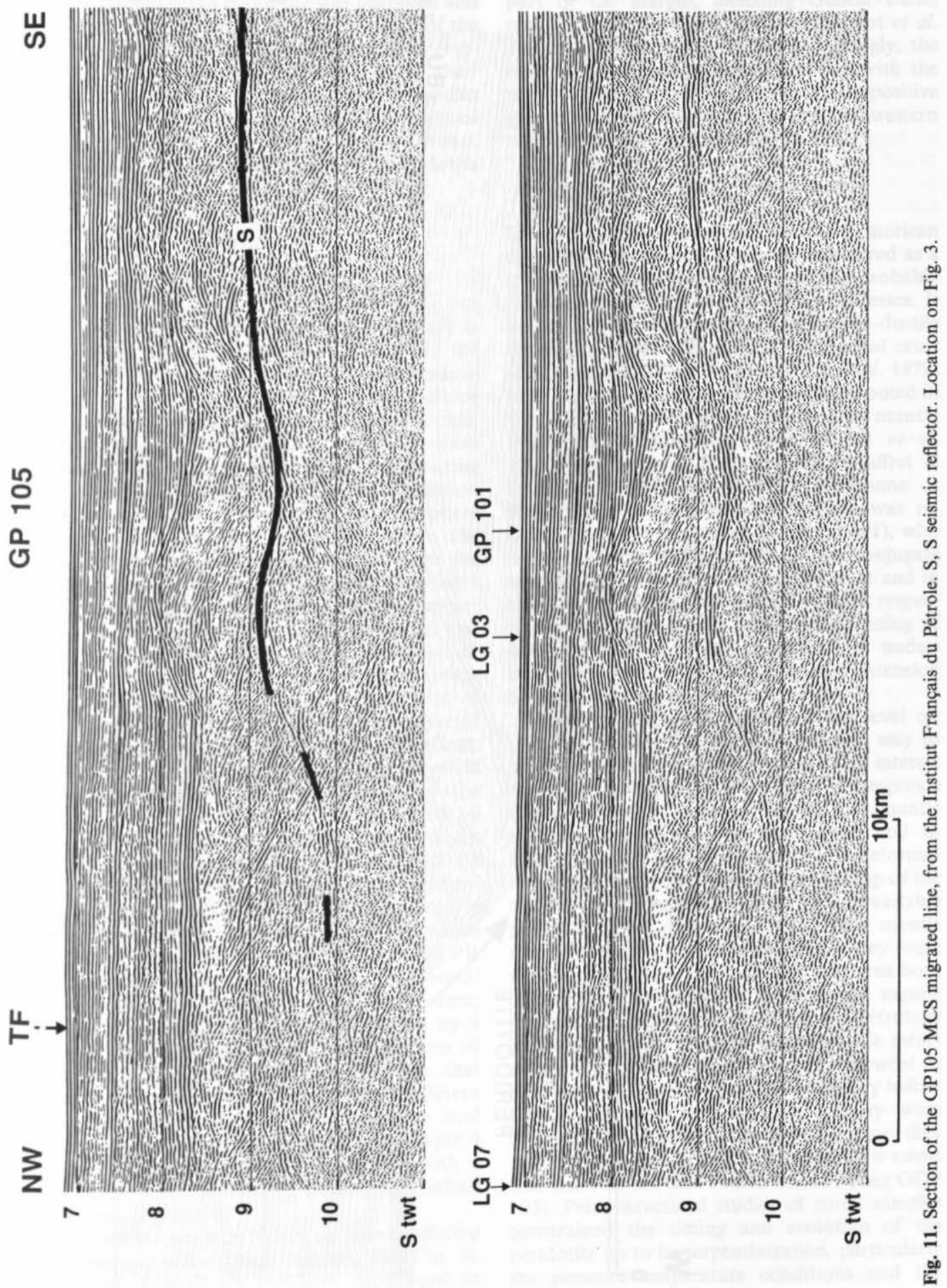


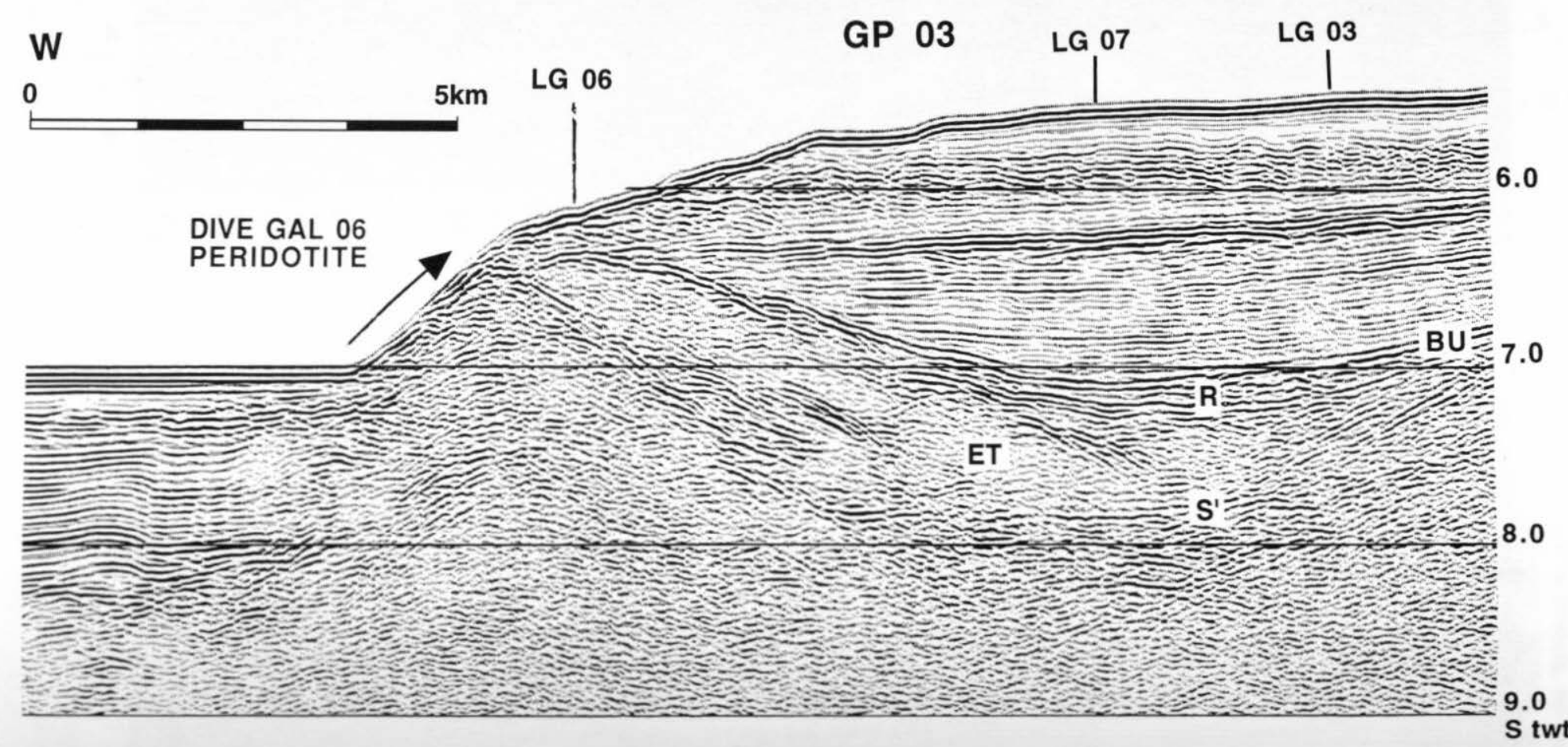

Fig. 12. Section of the GP03 MCS migrated line, from the Institut Français du Pétrole. The S' seismic reflector is connected with the top of the serpentinite body sampled at dive site 06. BU, break-up unconformity; ET, enigmatic terranes (layer 3); R, syn-rift sediments. See Figs 3 and 9 for location. 
Espinosa, 1986). The thickness of the reflective horizon increases considerably beneath the PR, where serpentinized peridotite was unroofed and is now free of crustal cover. To the south of the margin it is located at the level where Recq et al. (1991) placed the seismic Moho from their refraction study. All these data are consistent with the idea that the scattering zone of reflectivity is actually the reflective Moho, located at the fresh-serpentinized peridotite boundary.

\section{Discussion}

\section{The scattering reflective Moho (SRM)}

The fresh serpentinized peridotite boundary is also the palaeohydrothermal front, i.e. the surface where syn-rift hydrothermal serpentinization of mantle rocks stopped after seafloor spreading started and margin lithosphere cooled. The depth of the reflective Moho (7-8 km beneath the seafloor) is a clue for estimating the maximum depth of hydrothermal circulation during rifting within upper, brittle lithosphere covered by sea water. In areas where the continental crust thinned down to $7-8 \mathrm{~km}$ the syn-rift hydrothermal circulation probably reached the petrological Moho and the uppermost part of the mantle through the faulted and stretched basement of the margin. Boillot et al. $(1989 \mathrm{~b})$ proposed naming this process 'undercrusting': it involves accretion, at the base of highly stretched continental crust, of a layer of serpentinite which belongs to the lower seismic crust by its physical properties, although made of mantle-derived rocks. In the case of the Galicia margin the hypothesis is supported by the occurence of layer 4 along the entire margin with the same physical properties, and its connection with the OCB ridge where serpentinized peridotite was sampled in several places. It is confirmed by the continuity of the SRM which underlies layer 4 in the deep margin and the PR as well. Note that beneath thick continental crust the Moho has a very different signature; around France for example, it is marked by a strong, continuous reflection at the bottom of scattering lower crust (Rappin 1992). In that case, it probably bounds terranes very different in nature, while the high attenuation and scattering reflectivity at the base of the layer 4 of the Galicia margin is in agreement with a transition zone containing both serpentinized and fresh peridotite.

The SRM seems to be not or poorly affected by Cenozoic deformation beneath TF (Fig. 5). However, it shallows regularly northward as does the seafloor. From regional geological studies it is known that the uplift of the northern part of the margin, including Galicia Bank, resulted from Cenozoic tectonics (Boillot et al. 1979; Mougenot et al. 1984). Accordingly, the reflective Moho is regionally uplifted with the margin, thus accounting for the strong positive gravimetric anomaly located at the northwestern edge of the margin (Lalaut et al. 1981).

\section{The $S$ seismic reflector}

Since it was discovered beneath the Armorican and Galica margins, $\mathrm{S}$ has been considered as a major feature of these passive margins, probably a key for understanding the rifting processes. It was tentatively interpreted as the brittle-ductile transition within the thinned continental crust (de Charpal et al. 1978; Montadert et al. 1979) or as a major syn-rift detachment fault rooted in the lower ductile crust or in the mantle (Wernicke \& Burchfield 1982; Boillot et al. 1987; Le Pichon \& Barbier 1987; Mauffret \& Montadert 1987; Sibuet 1992; Hoffmann \& Reston 1992). Another interpretation was recently proposed by Beslier \& Brun (1991), who relate $\mathrm{S}$ to the development of two conjugate shear zones, located in the ductile crust and in the deeper ductile lithospheric mantle respectively. It is clear that a good understanding of the nature of $\mathrm{S}$ would improve our understanding of the processes of crustal extension leading to the creation of the margin.

Sampling the rocks located at the level of, upon and under $\mathrm{S}$ is the most efficient way to progress in this discussion. It is of most interest to verify that at first the reflector corresponds to the boundary between crustal and mantle terranes, as proposed in this paper, and to further specify the kinematics of the deformation at the base of the crust and at the top of the mantle. Unfortunately, until now, available petro-structural data come only from mantle rocks recovered in the area where they were unroofed by syn-rift tectonics. In that area both crustal terranes and their contact with mantle material are missing. However, the petrology and fabric of the exposed rocks provide information on the deformation they underwent in the vicinity of the crust-mantle boundary before they were unroofed, at least if they were preserved from superficial erosion since they were exposed on the seafloor. By chance it seems that this was the case at drill Site 637 (Leg ODP 103). Petro-structural studies of cored samples constrained the timing and evolution of the peridotite up to its serpentinization, particularly the pressure-temperature conditions and the 
kinematics of the ductile deformation (Agrinier et al. 1988; Féraud et al. 1988; Girardeau et al. 1988; Beslier et al. 1990). The results show that the evolution of the rocks is compatible with a progressive uplift beneath a continental rift, and moreover that ductile simple shear played a major part in the stretching of the lithosphere before it broke up at $114 \mathrm{Ma}$. After partial melting under asthenospheric conditions the plagioclase-bearing peridotites experienced intense ductile deformation under lithospheric conditions within a normal shear zone gently dipping toward the continent. From these data it is concluded that a shear zone was actually drilled at ODP Site 637. The kinematics and timing of the deformation are compatible with models of passive margin formation involving simple shear, either along a single normal synrift detachment fault rooted in the mantle (Boillot et al. 1987a), or in a ductile shear zone within the mantle (Beslier \& Brun, 1991; Brun \& Beslier in press).

The Galicia margin therefore provides a unique opportunity to study, in situ, the shearing of the upper mantle beneath a continental rift. However, the relationship between the drilled shear zone and the $\mathrm{S}$ reflector remains questionable (see the next section).

In the previous section, it was stressed that the $\mathrm{S}^{\prime}$ reflector and the surrounding terranes forming the northern segment of the Galicia margin have the same physical properties as $\mathrm{S}$ and layers 1-4 in the southern segment. In both cases, layer 4 , roofed by $\mathrm{S}-\mathrm{S}^{\prime}$, is probably made, at least partly, of serpentinized peridotite sampled by drilling and by diving. Moreover, the crustal structure of the OCB and adjacent margin seems to be similar in the Iberia Abyssal Plain (IAP) further south. Here, the OCB is marked by a basement ridge (Fig. 2) with seismic characteristics and tectonic setting comparable to those of the Galicia margin PR. The deepest tilted block of the IAP margin is underlain by a strong seismic reflector $\mathrm{S}^{\prime \prime}$ similar to $\mathrm{S}^{\prime}$ and $\mathrm{S}^{\prime}$ (Beslier et al. 1993), and $S^{\prime \prime}$ is located at the level where Whitmarsh et al. (1990) placed the boundary between upper and lower seismic crust, with respective seismic velocities of 6.2 and $7 \mathrm{~km} \mathrm{~s}^{-1}$ or more. Such a similarity of the seismic images and seismic velocities with those recorded and measured on the Galicia margin strongly suggests that the terranes resting at the base of the IAP thinned continental crust are also made of serpentinized peridotite (Beslier et al. 1993; Whitmarsh et al. 1993).

The crustal structure is thus very similar in the different segments of the west Iberia margin and adjacent OCB. The ubiquitous occurrence of a strong reflector $\left(\mathrm{S}, \mathrm{S}^{\prime}\right.$ or $\left.\mathrm{S}^{\prime \prime}\right)$ at the same structural level reinforces the interest to investigate it and surrounding terranes.

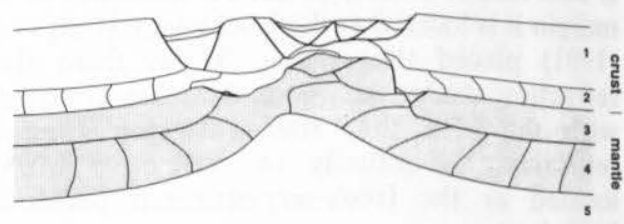

A

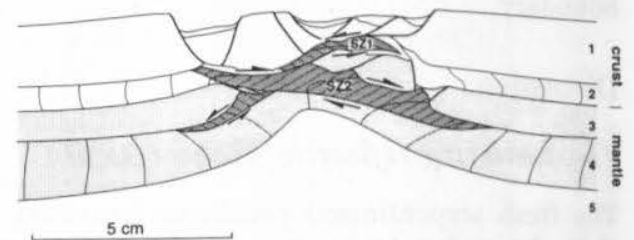

B

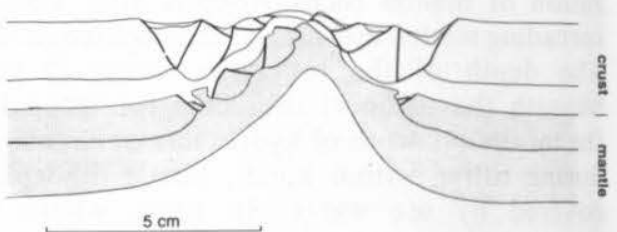

Fig. 13. Analogue modelling of the lithosphere stretching. Brittle continental crust (1) and brittle mantle (3) are modelled by sand, ductile continental crust (2) and ductile lithospheric upper mantle (4) by silicone putties, asthenosphere (5) by golden syrup. Senses of shear are inferred from the deformation of passive markers included in brittle and ductile layers. (A) Model 1, moderately stretched (shear zones in dark grey); (B) model 2, highly stretched. SZ1 and SZ2, shear zones discussed in the text. From Beslier \& Brun (1991).

\section{Conceptual model for the formation of the} Galicia passive margin

To build up this conceptual model, we started from two different sets of data.

Firstly, analogue modelling of the lithosphere stretching was ușed (description of models and their inferences for passive margins formation, including Galicia margin, are detailed in Beslier 1991; Beslier \& Brun 1991; Brun \& Beslier in press). This takes into account the differential mechanical behaviour of the main lithospheric rheological layers, and allows the study of the stretching mechanisms of the lithosphere and the related crustal thinning processes during a rifting episode (Faugère \& Brun, 1984; Vendeville et al. 1987; Allemand et al. 1989; Allemand \& Brun 1991; Beslier \& Brun 1991; Brun \& Beslier in press). The rheological structure of the 
lithosphere is simplified in the experiments by a brittle-ductile layered model, which is a good approximation of the structure of a stable continental lithosphere with a normal geothermal gradient (e.g. Ranalli \& Murphy 1987; Davy \& Cobbold 1991). The experimental analogue materials are dry sand for brittle behaviour and silicone putties for ductile behaviour. The four layers represent the upper brittle crust (sand), the lower ductile crust (silicone putty), the uppermost brittle mantle and the upper lithospheric ductile mantle. This hithospheric structure lays upon golden syrup which simulates the asthenospheric behaviour. The model is submitted to localized horizontal extension (see Beslier 1991; Davy \& Cobbold 1991 for details on the method). Figure 13A shows a crosssection of a model at the end of the experiment. Brittle layers (upper crust and uppermost mantle) underwent boudinage, while ductile layers accommodated the boudinage by simple shear along conjugate normal shear zones. With progressive extension, the rupture of the brittle mantle is achieved in one of the necked zones, where the deformation is localized at depth. In the last stage of the rifting two main shear zones accommodate the stretching beneath the rift, the right part of which accounts for the west Galicia margin structure (Fig. 13A): one (SZ1), located in the lower ductile crust, acts with a top-tothe-west sense of shear, and accounts for the continentalward sense of blocks tilting sense in the upper brittle crust; the other one (SZ2), connecting the ductile crust and the ductile mantle in the ruptured zone of the brittle mantle, acts with an opposite sense, i.e. top-to-the-east. Another model (Fig. 13B), identical though extremely thinned, shows that the lower ductile crust can disappear at the rift axis, bringing the mantle directly in contact with the upper crustal blocks, or even with the syn-rift sediments as observed on the Galicia margin.

Secondly, structural data from the Galicia margin have been used. We have already discussed the kinematics of the peridotite ductile deformation established from petro-structural studies of samples recovered on the PR: the mantle rocks have been deformed in a normal ductile shear zone dipping northeast, with a topto-the-east shear sense. Thus, the results of the analogue models are in good agreement with the available structural data from the margin. Two major shear zones are postulated, SZ1 in the ductile crust, and $\mathrm{SZ} 2$ rooted in the ductile lithospheric mantle (Figs 13A \& 14A). Currently, only SZ2 has been sampled by drilling and diving on the peridotite ridge, and Boillot $e t$ $a l$. $(1987 a, b, 1988 b, 1989 b)$, developing the initial model of Wernicke (1985), considered it as part of a detachment fault rooted in the mantle. However, the sense of blocks tilting on the margin also implies the existence of SZ1 (Faugère \& Brun 1984; Brun \& Beslier in press). From this point in the discussion two interpretations are possible, although closely related. Reston et al. (this volume) propose $\mathrm{S}$ to be related to $\mathrm{SZ1}$, and the tectonic unroofing of $\mathrm{PR}$ to SZ2. Some of the current authors (G.B., M.O.B., D.R.) rather believe that the tectonic contact between upper crust material (the tilted blocks of the margin) and mantle material (the serpentinized peridotite) relates to both shear zones (Beslier \& Brun 1991). This interpretation is supported by the highly stretched experimental model (Fig. 13B), which accounts for the contact between upper crust and upper mantle terrane. In that case, which corresponds to the final stage of the rifting, the lower crust is extremely thinned and even lost in the vicinity of the rift axis, at the places where the upper brittle mantle is broken (Fig. 13B). As a result, the upper, brittle crust lies either directly over mantle terranes deformed in SZ2 or on interbedded lenses of sheared lower crust initially belonging to SZ1. Therefore, we suspect tectonic melange of various thickness and including sheets of lower crust to be related to the S reflector beneath the deeper crustal tilted blocks (Fig. 14B). Moreover, the serpentinization of mantle rocks beneath the very stretched crust at the rift axis does change the rheological behaviour of mantle terranes. It is thus possible that decollement of tilted blocks occurs at the top of the upper mantle in the final stage of the rifting (Beslier \& Brun 1991).

Figure 14C summarizes the crustal structure of the deep Galicia margin from this study. In the deepest part of the margin, thin blocks of upper continental crust are scattered on "undercrusted' serpentinite, $\mathrm{S}$ being the tectonic contact between the blocks and the serpentinized uppermost mantle. However, intercalation between these terranes of sheared lower continental crust is possible locally. Deeper is the fresh-serpentinized peridotite boundary, i.e. the actual seismic Moho. To the east, where the continental crust thickens, 'true' lower continental crust is expected in place of the serpentinite layer. The nature of the lateral transition between the two kinds of lower seismic crust (serpentinized peridotite in the most stretched area; lower continental crust elsewhere) remains a target for further clarification and discussion. Nevertheless, the disappearance of $\mathrm{S}$ beneath the tilted blocks of the eastern, upper part of the margin may be a consequence of the transition. 

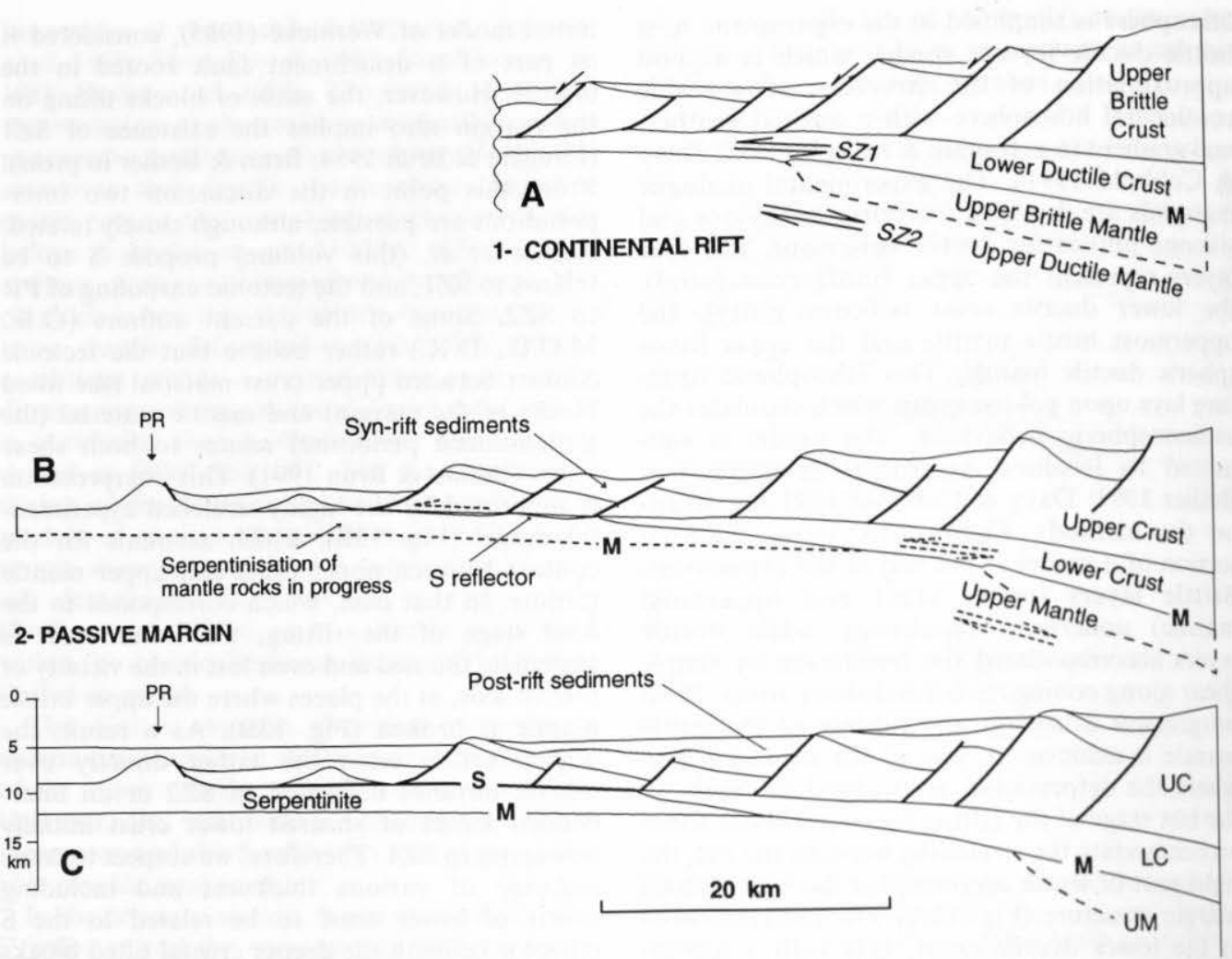

Fig. 14. Conceptual model $[(\mathbf{A})$ and $(\mathbf{B})]$ and schematic cross-section $[(\mathbf{C})]$ of the deep passive Galicia margin. The conceptual model is derived from the analogue modelling depicted in Fig. 13. It describes two representative stages of margin rifting: during continental rifting, and just before seafloor spreading starts (after Beslier \& Brun 1991; Brun \& Beslier in press). (C) is established along $42^{\circ} \mathrm{N}$.

\section{Plate kinematic implications of margin segmentation}

Beslier et al. (1993) suggested that the segmentation of the ridge marking the OCB results from discontinuous, northward propagation of continental break-up and opening of the North Atlantic in early Cretaceous time. Moreover, the SW-NE transverse fault offsetting R1 and R2 (Fig. 3) and R3-R4 (Fig. 2) segments can be interpreted as transfer faults indicating the direction of lithosphere stretching during rifting. In the southern segment of the Galicia margin, SW-NE is also the direction of shearing in mantle rocks recovered on the PR (Girardeau et al. 1988; Beslier et al. 1990) and the main direction of transverse faults (Thommeret et al. 1988). Thus, we suspect that the lithosphere underwent stretching along the present SW-NE direction during rifting, with consequences for the correct location and identification of the conjugate margin in the Newfoundland Basin.

\section{Summary and conclusions}

(1) The seismic crust of the deep Galicia Margin is made of four main layers characterized by their seismic facies, seismic velocities, and attenuation of reflected $\mathrm{P}$ waves and related reflectivity. Sediments (layers 1 and 2) are classically divided into syn- and post-rift sequences, separated by the post-rift or break-up (BU) unconformity. A reflector of high reflectivity emphasizes the BU. Within the sediments, the attenuation of seismic waves is high, the seismic image is layered, and the velocity ranges from 2.2 to $3.5 \mathrm{~km} \mathrm{~s}^{-1}$. Faulted layer 3 (enigmatic terrane) rests on the reflector $\mathrm{S}-\mathrm{S}^{\prime}$, another level of high reflectivity. Within ET the velocity ranges from 4 to $5.7 \mathrm{~km} \mathrm{~s}^{-1}$, and the attenuation of seismic waves is moderate and constant at places where no Cenozoic tectonics occurred. 
The layer includes continental basement and lithified pre-rift sediments sampled from the thinned, upper crust of the margin. The lower seismic crust (layer 4) is characterized by low attenuation of seismic waves, high seismic velocities $\left(7.0 \mathrm{~km} \mathrm{~s}^{-1}\right.$ or more), and rests on a scattering, poorly reflective Moho located at the level of the refractive Moho. Correlation with terranes sampled at the OCB shows that the main component of this layer is serpentinized peridotite, resulting from syn-rift hydrothermal alteration of the uppermost mantle. Layer 4 rests on fresh peridotite of the upper mantle at the seismic Moho. (2) The Galicia OCB is marked by a basement ridge made of serpentinized peridotite. It corresponds to the early Cretaceous rift axis, and results from tectonic unroofing of the mantle terranes in the latest stage of margin rifting. Mantle rocks were ductily sheared under lithospheric conditions before their serpentinization and brittle deformation, in agreement with lithosphere stretching models involving simple shear. Two syn-rift shear zones at least are necessary to account for the present margin structure: one (SZ1) located in the lower ductile crust, synthetic to the continentalward tilting of crustal blocks; another (SZ2) rooted in the ductile mantle, a part of which is now exposed beneath sediments at the OCB (PR). (3) The OCB and adjacent margin are divided into two segments by a transverse Mesozoic structure that was partly reactivated and inverted in Cenozoic times. The NE-SW orientation of this transverse structure suggests that the stretching of the lithosphere occurred in early Cretaceous time along the NE-SW direction. (4) The S-S' reflector is considered to be the seismic signature of the contact beween crustal material of the margin and underlying serpentinized peridotite. The actual nature of this contact constitutes an important target for further research. We propose that it is related to the extreme thinning of the lithosphere in the vicinity of the rift axis (now the deepest part of the margin), a place where the extension tends to localize in the latest stage of the rifting. Here, the top of the mantle deformed in SZ2 is put into contact either with the ductile crust deformed in SZ1 or with the base of the upper crust. Thus, we believe $S-S^{\prime}$ to be a major tectonic contact between crustal and mantle material, related to both shear zones SZ1 and SZ2. (5) We conclude that it is of most interest to sample by drilling the terranes located above, at the level of and beneath S-S'. From petro-structural studies of cored samples it is expected that the timing, kinematics and temperature-pressure conditions of the deformation will be investigated; and further, to constrain better the mechanisms of lithosphere stretching and passive margins formation.

We thank Captain J. C. Delmas and the crew of the O. V. Vessel 'Le Suroit'; J. Hervéou and the technical team responsible for the acquisition of multichannel seismic reflection data during the Lusigal cruise (1990); IFREMER and GENAVIR for technical and financial support. The Institut Français du Pétrole, who provided MCS data (GP03 seismic line); CNRS-INSU (IST Program) for financial support of the MCS data processing; Institut de Physique du Globe de Strasbourg (France), and GEOMAR in Kiel (Germany), where MCS data were processed. R. Scrutton helped us to improve the English in the manuscript.

Contribution no. 609 of the Groupe d'Etude de la Marge Continentale et de l'Océan (GEMCO), URA 718 du CNRS et de l'Université P. et M. Curie (Observatoire Océanologique de Villefranche-SurMer).

\section{References}

Agrinier, P., Mevel, C. \& Girardeau, J. 1988. Hydrothermal alteration of the peridotites cored at the ocean-continent boundary of the Iberian margin: petrologic and stable isotope evidence. In: BoIllot, G., Winterer, E. L., ET AL. (eds) Proceedings ODP, Science Results, 103, College Station, TX (Ocean Drilling Program), 225-233.

Allemand, P. \& BRUN, J. P. 1991. Width of continental rifts and rheological layering of the lithosphere. Tectonophysics, 188, 63-69.

- DAVY, P. \& VAN DEN DRIESSCHE, J. 1989. Symétrie et asymétrie des rifts et mécanismes d'amincissement de la lithosphère. Bulletin de la Société Géologique de France, 8, 445-451.

Beslier, M. O. 1991. Formation des marges passives et remontée du manteau: modélisation expérimentale et exemple de la marge de la Galice. Mém. Docum. Centre Arm. Et. Struct. Socles, Rennes, 45.

\& BRUN, J. P. 1991. Boudinage de la lithosphère et formation des marges passives. Comptes Rendus de l'Académie des Sciences, Paris, 313, 951-958.

$\longrightarrow$, Ask, M. \& BoIllot, G. 1993. Oceancontinent boundary in the Iberia Abyssal Plain from multichannel seismic data. Tectonophysics, 218, 383-393.

-, Girardeau, J. \& Bolllot, G. 1990. Kinematics of peridotite emplacement during North Atlantic continental rifting, Galicia, NW Spain. Tectonophysics, 184, 321-343.

Boillot, G., Beslier, M. O. \& Comas, M. 1992. Seismic image of undercrusted serpentinite beneath a rifted margin. Terra Nova, 4, 25-33.

, GirardeAu, J. \& KornProbst, J. 1988b. The rifting of the Galicia margin: crustal thinning and emplacement of mantle rocks on the seafloor. In: BOILlot, G., Winterer, E. L., ET AL. (eds) Proceedings ODP, Science Results, 103, College Station, TX (Ocean Drilling Program), 741-756. 
- Féraud, G., RecQ, M. \& Girardeau, J. $1989 b$. 'Undercrusting' by serpentinite beneath rifted margins: the example of the west Galicia margin (Spain). Nature, 341, 523-525.

-, Mougenot, D., Girardeau, J. \& Winterer, E. L. 1989a. Rifting processes on the west Galicia margin, Spain. In: TANKARD, A. J. \& BALKWILL, H. R. (eds) Extensional Tectonics and Stratigraphy of the North Atlantic Margins, American Association of Petroleum Geologists Memoir, 46, 363377.

, Auxiètre, J. L., Dunand, J. P., Dupeuble, P. A. \& MAUfFret, A. 1979. The northwestern Iberian Margin: a Cretaceous passive margin deformed during Eocene. In: TALWANI, M., Hayet, W. \& Ryan, W. B. F. (eds) Deep Drilling Results in the Atlantic Ocean: Continental Margins and Paleoenvironment. Maurice Ewings Series 3, Washington DC, American Geophysics Union, 138-153.

$\longrightarrow$, Grimaud, S., Mauffret, A., Mougenot, D., KORNPROBST, J., MERgoIl-Daniel, J. \& TORRENT, G. 1980. Ocean-continent boundary off the Iberian margin: a serpentinite diapir west of the Galicia Bank. Earth \& Planetary Science Letters, 48, 23-34.

- Comas, M. C., Girardeau, J. et al. $1988 a$. Preliminary results of the Galinaute cruise: dives of the submersible Nautile on the western Galicia margin, Spain. In: BoILlot, G., Winterer, E. L., ET AL. Proceedings ODP, Science Results, 103, College Station, TX (Ocean Drilling Program), 37-51.

, RecQ, M., Winterer, E. L. ET AL. $1987 a$. Tectonic denudation of the upper mantle along passive margins: a model based on drilling results (ODP leg 103, western Galicia margin, Spain). Tectonophysics, 132, 335-342.

- Winterer, E. L., MEYER, A. W. ET AL. 1987 b. Proceedings, Initial Reports (Pt A), ODP, 103. College Station, TX (Ocean Drilling Program).

, - ET AL, 1988c. Proceedings ODP, Science Results, 103. College Station, TX (Ocean Drilling Program).

Brun, J. P. \& Beslier, M. O. (in press). Mantle exhumation at passive margin. Earth and Planetary Science Letters.

De Charpal, O., Guennoc, P., Montadert, L. \& ROBERTS, D. G. 1978. Rifting, crustal attenuation and subsidence in the Bay of Biscay. Nature, 275, 706-711.

DAvY, P. \& Coвbold, P. 1991. Experiments on shortening of a 4-layer model of the continental lithosphere. Tectonophysics, 188, 1-25.

Dix, C.H. 1955. Seismic velocities from surface measurements. Geophysics, 20, 68-86.

FAugére, E. \& BRun, J. P. 1984. Modélisation expérimentale de la distension continentale. Comptes Rendus de l'Académie des Sciences. Paris, 299, 365-370.

Féraud, G., Girardeau, J., Beslier, M. O. \& BoIllot, G. 1988. Datation 39Ar/40Ar de la mise en place des péridotites bordant la marge de la Galice (Espagne). Comptes Rendus de l'Académie des Sciences, Paris, 307, 49-55.

Girardeau, J., Evans, C. A. \& Beslier, M. O. 1988. Structural analysis of plagioclase-bearing peridotites emplaced at the end of continental rifting: hole 637A, ODP leg 103 on the Galicia margin. In: BoIllot, G., Winterer, E. L., ET AL. (eds) Proceedings ODP, Science Results, 103, College Station, TX (Ocean Drilling Program), 209-223.

Grimaud, S., Boillot, G., Collette, B., Mauffret, A., Miles, P. R. \& Roberts, D. B. 1982. Western extension of the Iberian-European plate boundary during the early Cenozoic (Pyrenean) convergence: a new model. Marine Geology, 45, 63-77.

Herraiz, M. \& EsPinosA, A. F. 1986. Scattering and attenuation of high-frequency seismic waves: development of the theory of coda waves. Open File Report, 86-455, US Geological Survey, 1-92.

Hoffmann, H. J. \& Reston, T. J. 1992. The nature of the $\mathrm{S}$ reflector beneath the Galicia Bank rifted margin. Preliminary results from pre-stack depth migration. Geology, 20, 1091-1094.

HORSEFIELD, S. J. 1992. Crustal structure across the continent-ocean boundary. $\mathrm{PhD}$ Thesis, University of Cambridge, UK.

KENT, D. V. \& Gradstein, F. M. 1986. A Jurassic to Recent chronology in the western North Atlantic region. In: VoGT, P. R. \& TUCHOLKE, B. E. (eds) Geology of North America, Geological Society of America, Boulder, CO, vol. M, 45-50.

Lalaut, P., Sibuet, J. C. \& Williams, C. A. 1981. Présentation d'une carte gravimétrique de l'Atlantique du nord-est. Comptes Rendus de l'Académie des Sciences, Paris, D, 292, 597-600.

Lallemand, S., Mazé, J. P., Monti, S. \& Sibuet, J. C. 1985. Présentation d'une carte bathymétrique de l'Atlantique Nord-Est. Comptes Rendus de l'Académie Sciences, Paris, 300, 145-149.

Le Pichon, X. \& BARBIER, F. 1987. Passive margin formation by low-angle faulting within the upper crust: the northern Bay of Biscay margin. Tectonics, 6, 133-150.

Malod, J. A., Murillas, J., Kornprobst, J. \& BoILlot, G. 1993. Oceanic lithosphere at the edge of a Cenozoic active continental margin (northwest slope of Galicia Bank, Spain). Tectonophysics, 221.

Mamet, B., Comas, M. C. \& Bolllot, G. 1991. Late Palezoic basin on the west Galicia Atlantic margin. Geology, 19, 738-741.

MAuffret, A. \& Montadert, L. 1987. Rift tectonics on the passive continental margin off Galicia (Spain). Marine Petroleum Geology, 40, 49-70.

\& 1988. Seismic stratigraphy off Galicia. In: BoIllot, G., WINTERer, E. L. ET AL. (eds) Proceedings ODP, Science Results, 103. College Station, TX (Ocean Drilling Program), 13-30.

Montadert, L., De Charpal, O., Roberts, D. G., GuenNOC, P. \& Sibuet, J. C. 1979. Northeast Atlantic passive continental margins: rifting and subsidence processes. In: TALWANI, M., HaY, W. \& RYAN, W. B. F. (eds) Deep Drilling Results in the Atlantic Ocean: Continental Margins and Paleoenvironments. American Geophysical Union, 
Maurice Ewing Series, 3, 154-186.

Mougenot, D., KIDD, R. B., Mauffret, A., Regnauld, H., Rothwell, R. G. \& VANNEy, J. R. 1984. Geological interpretation of combined Sea-Beam, Gloria, and seismic data from Porto and Vigo Seamounts, Iberian continental margin. Marine Geophysics Research, 6, 329-363.

Murillas, J., Mougenot, D., Boillot, G., Comas, M. C., BANDA, E. \& Mauffret, A. 1990. Structure and evolution of the Galicia interior basin (Atlantic western Iberian continental margin). Tectonophysics, 184, 297-319.

Ranalli, G. \& Murphy, D. C. 1987. Rheological stratification of the lithosphere. Tectonophysics, 132, 281-295.

RAPPIN, D. 1992. Apport des analyses d'amplitude et temps-fréquence à l'exploitation de données de sismique profonde. Thèse de l'Université Louis Pasteur de Strasbourg.

- Marthelot, J. M., De Bazelaire, E. \& RAVAT, J. (in press). Analysis of the attenuation of amplitudes on records of the ECORS Pyrenees deep seismic profile. Geophysical Prospecting.

RecQ, M., Whitmarsh, R. B. \& Sibuet, J. C. 1991 Anatomy of a lherzolitic ridge, Galicia margin. Terra Abstract, 3, 122

Reston, T. J., KrawczYK, C. M. \& Hoffmann, H. J. 1995. Detachment tectonics during Atlantic rifting: analysis and interpretation of the $\mathrm{S}$ reflector, the west Galicia margin. This volume,

SibUET, J. C. 1992. New constraints on the formation of the non-volcanic continental Galicia-Flemish Cap conjugate margins. Journal of the Geological Society, London, 149, 829-840.

-, Mazé, J. P., Amortila, P. \& Le Pichon, X. 1987. Physiography and structure of the western Iberian continental margin off Galicia from SeaBeam and seismic data. In: BoIllot, G., WIN-
TERer, E. L., Meyer, A. W. ET $A L$. (eds) Proceedings Initial Reports (A). ODP, 103, 77-97. -, RYAN, W. B. F. ET AL. 1979. Initial Reports of the Deep Sea Drilling Project, 47. US Government Printing Office, Washington, DC.

Srivastava, S. P., Roest, W. R., Kovacs, L. C., OAKey, G., Lévesque, S., Verhoef, J. \& MACNAB, R. 1990. Motion of Iberia since the Late Jurassic: Results from detailed aeromagnetic measurements in the Newfoundland Basin. Tectonophysics, 184, 229-260.

Thommeret, M., Boillot, G. \& Sibuet, J. C. 1988. Structural map of the Galicia margin. In: Boillot, G., Winterer, E. L. ET AL. (eds) Proceedings ODP, Science Results, 103. College Station, TX (Ocean Drilling Program), 31-36.

Vendeville, B., CoBbold, P. R., Davy, P., Brun, J. P. \& Choukroune, P. 1987. Physical models of extensional tectonics at various scales. In: Cow. ARD, M. P., DEWEY, J. F. \& HANCOCK, P. L. (eds) Continental extensional tectonics. Geological Society, London, Special Publication, 28, 95-107.

WERNICKE, B. 1985. Uniform-sense normal simple shear of the continental lithosphere. Canadian Journal of Earth Sciences, 22, 108-125. - \& BurchField, B. C. 1982. Modes of extensional tectonics. Journal of Structural Geology, 4, 105-115.

Whitmarsh, R. B., Miles, P. R. \& Mauffret, A. 1990. The ocean-continent boundary off western continental margin of Iberia - I. Crustal structure at $40^{\circ} 30^{\prime}$ N. Geophysics Journal International, 509 531 .

, Pinheiro, L. M., Miles, P. R., RecQ, M. \& Sibuet, J. C. 1993. Thin crust at the western Iberia ocean-continent transition and ophiolites. Tectonics, 12, 1230-1239. 